\title{
RAT AND MOUSE BRAIN HISTAMINE $N$-METHYLTRANSFERASE: MODULATION BY METHYLATED INDOLEAMINES ${ }^{1}$
}

\author{
O. Z. Sellinger, R. A. Schatz and W. G. Ohlsson \\ Laboratory of Neurochemistry, Mental Health Research Institute. University of Michigan \\ Medical Center, Ann Arbor, MI 48109, U.S.A.
}

(Received 16 March 1977. Accepted 28 July 1977)

\begin{abstract}
A purification procedure for rat and mouse brain histamine $N$-methyltransferase (HMT, EC 2.1.1.8) is described which achieves the preparation of 87 -fold purified rat brain and 166-fold purified mouse brain enzyme. The purified HMT (MW 29,000) is inhibited by a number of physiologically and pharmacologically active amines, among them several methylated indoleamines. at concentrations above $5 \times 10^{-6} \mathrm{M}$. At concentrations below $1 \times 10^{-7} \mathrm{M}$, most of the methylated indoleamines stimulate HMT, provided histamine is maintained at, or close to, its optimal concentration as an HMT substrate, namely $1 \times 10^{-5} \mathrm{M}$. A study of the nature of the inhibitory process revealed a non-competitive inhibition of HMT by dopamine as against a competitive inhibition of the enzyme by most methylated indoleamines. Increasing the concentration of histamine beyond the optimal value, i.e. to inhibitory levels, resulted in less stimulation. The findings support the notion that MSO elicits the formation in selected brain cells of supranormal amounts of several methylated indoleamines which are able to stimulate HMT (and possibly other methyltransferases, see SALAS et al., 1977), thereby causing the depletion of the cerebral levels of $S$-adenosyl-L-methionine, reported previously (SCHAtz \& SELlinger, 1975b).
\end{abstract}

THE PRINCIPAL catabolic pathway for histamine in rodent brain is by methylation to $1-$ methyl histamine ${ }^{2}$ and by further oxidation of the latter to 1-methylimidazoleacetic acid. As we have recently shown (SCHATz \& SELLINGER, 1975a), the activity catalyzing the methylation of histamine, histamine $N$-methyltransferase (HMT, EC 2.1.1.8) becomes elevated in both mouse and rat brain following the administration of the convulsant agent L-methionine-dl-sulfoximine (MSO). Since this treatment also leads to a marked depletion of cerebral $S$-adenosyl-L-methionine (SCHATz \& SELLINGER, 1975b), we proposed (Schatz \& Sellinger, 1975a) that MSO elicits the accumulation within selected brain cells of methylated HMT-stimulating substances. To begin testing this notion, we decided to examine first the effectiveness of several naturally occurring and biologically potent (ROSENGARTEN \& FriedHOFF, 1976; Gillin et al., 1976a) methylated indoleamines as HMT modulators in vitro. To ensure a high specificity of interaction between the methylated indoleamines and the HMT protein, we purified HMT from mouse and rat brain and we also tested the effect of several of the amines found active with

\footnotetext{
'Supported by a United States Public Health Service grant. NINCDS 06294.

Abbreviations used: HMT, histamine $N$-methyltransferase; MSO, L-methionine-dl-sulfoximine; PNMT, phenylethanolamine $N$-methyltransferase; DTT, dithiothreitol; COMT. catechol $O$-methyltransferase.

${ }^{2}$ By the 'histamine nomenclature' (see BARTH et al.. 1973). In the 'histidine nomenclature' (see Schayer \& ReILLY, 1975) this is 3-methylhistamine.
}

HMT on another methyltransferase, phenylethanolamine $N$-methyltransferase (PNMT, EC 2.1.1.28). In addition, we purified HMT from brains of MSOtreated animals and compared its interaction with $N, N$-dimethyltryptamine to that of the control enzyme. A preliminary account of some of the findings has appeared (SEllinger et al., 1976).

\section{EXPERIMENTAL PROCEDURES}

Animals. Adult, male Sprague-Dawley rats $(200-250 \mathrm{~g})$ and male Swiss-Webster mice (20-25 g) (Spartan Research Animals, Haslett, MI) were killed by decapitation and the brains (minus the cerebellum) rapidly excised and weighed. Usually $15-21 \mathrm{~g}$ of rat and $9-14 \mathrm{~g}$ of mouse brain were worked up.

Chemicals. The following substances were purchased from Sigma Co. (St. Louis, MO): dithiothreitol (DTT), ammonium sulfate (enzyme grade), sucrose (enzyme grade), DL-norepinephrine $\mathrm{HCl}$, L-epinephrine, tryptamine $\mathrm{HCl}$, imidazole, 3-hydroxytyramine $\mathrm{HCl}, 2$-methylimidazole. $\mathrm{N}, \mathrm{N}$-dimethyltryptamine, 5-hydroxytryptamine. 5-hydroxyDL-tryptophan, 5-hydroxyindoleacetic acid, 3-methoxytyramine, L-3-methoxytyrosine, L-1-methylhistidine, N,Ndimethyl-5-methoxytryptamine $\mathrm{HCl}, 5$-methoxytryptamine HCl, L-tryptophan, $\alpha$-methyl-DL-histidine-diHCl, 5-methoxy-DL-tryptophan and L-3-methylhistidine. Regis Chemical Co., Morton Grove, IL supplied $N$-methyl-3-hydroxytyramine $\mathrm{HCl}, \mathrm{N}$-methyl-5-hydroxytryptamine hydrogen oxalate, DL-octopamine $\mathrm{HCl}$, 4-methoxy-3-hydroxyphenethylamine $\mathrm{HCl}$, 4-methoxyphenethylamine $\mathrm{HCl}$, 3,4-dimethoxyphenethylamine $\mathrm{HCl}$, synephrine. melatonin. DL-3- $\alpha$-dimethyl-tyrosine methyl ester $\mathrm{HCl} . N$-methyltryptamine and $N$-acetyl dopamine. Tyramine $\mathbf{H C l}$. L-dihydroxyphenylalanine and phenylethanolamine were from 
ICN, Cleveland, OH. S-Adenosyl-L-methionine (hydrogen sulfate) was from Bochringer Mannheim Biochemicals. Indianapolis, $\mathrm{IN}$; imidazoleacetic acid $\mathrm{HCl}, \alpha$-methyl-DL-tyrosine and 1-methyl-4-imidazoleacetic acid were from CalBiochem. LaJolla. CA; N,N-dimethyl-5-hydroxytryptamine was from Aldrich Biochemicals. Milwaukee, WI and phenylethanolamine $\mathrm{N}$-methyltransferase (rabbit adrenal medulla) from Miles Laboratories. Elkhart. IN. DEAE-cellulose was a product of Whatman. Inc., Clifton. NJ: Sephadex G-100 and the protein molecular weight calibration kit were from Pharmacia. Piscataway. NJ. $S$-Adenosyl-L-[Me- ${ }^{14} \mathrm{C}$ ]methionine (spec.act. $40-65 \mathrm{mCi} / \mathrm{mmol}$ ) was from New England Nuclear. Boston. MA or from Research Products International, Elk Grove Village. IL. PCS (phase combining system) used in liquid scintillation counting was from Amersham/Searle. Arlington Heights, IL. All other chemicals were of the best reagent grade available.

Chromatography and related procedures. Chromatographic procedures were carried out on columns and with accessories supplied by Pharmacia, Piscataway. NJ. Dialysis and desalting were by means of the hollow fiber device (BioRad 50) (BioRad Laboratories, Richmond, CA) and reductions of volume by means of stirred cells provided with XM-50 filters (Amicon Corp.. Lexington. MA).

Assay of histamine N-methyltransferase. HMT was assayed according to SNYDER \& AXELROD (1965) under conditions described in a previous paper (SCHATZ \& SELLINGER. 1975a). Authentic 1-[Me- $\left.{ }^{14} \mathrm{C}\right]$ methylhistamine was prepared as previously described (SCHATz \& Sellinger, 1975a) and $1 \times 10^{-5} \mathrm{M}$-histamine was used as substrate. higher concentrations proving inhibitory (Schatz \& SELlINGER, 1975a). The concentration of $S$-adenosyl-L-methionine (including $\mathrm{S}$-adenosyl-L-[Me- $\left.{ }^{14} \mathrm{C}\right]$ methionine) was maintained at $3.2 \times 10^{-5} \mathrm{M}$ throughout the study. The blank tubes contained no histamine. All test-substances were initially tested for interference in the HMT assay (TAYLOR \& SNYDER, 1972) by adding them to the incubation mixtures either before or at the end of the incubation and then proceeding with the extraction steps. None of the substances tested was found to interfere with the quantitative extraction of $1-\left[\mathrm{Me}-{ }^{14} \mathrm{C}\right]$ methylhistamine, the only detectahle reaction product (Schatz. Ashcraft \& Sellinger. unpublished observations) of cerebral HMT and none was found to affect the $\mathrm{pH}$ of the incubation mixture.

PNMT was assayed according to DeguchI \& Barchas (1971) under the precise conditions more recently described by LEw et al. (1976). with phenylethanolamine as substrate. The above tests for interference were repeated and found satisfactory.

Protein was determined by the method of Lowry et al. (1951).

The administration of MSO. Injections were intraperitoneal, at a dose of $0.97 \mathrm{mmol} / \mathrm{kg}$. The animals were killed $3 \mathrm{~h}$ after the single dose.

The purification of histamine N-methyltransferase from mouse and rat brain. The weighed brains were homogenized in $10 \mathrm{vol}$ of $0.25 \mathrm{M}$-sucrose and the homogenate centrifuged at $80,000 \mathrm{~g}$ for $30 \mathrm{~min}$ in Beckman rotor $\mathrm{SW}-27$. Solid ammonium sulfate was added to the resulting supernatant to achieve $45 \%$ saturation $\left(4{ }^{\circ} \mathrm{C}\right)$ and the resulting precipitate was centrifuged off. The supernatant was brought to $80 \%$ saturation and the precipitate collected and suspended by gentle stirring in a volume of $10 \mathrm{~mm}-\mathrm{Na}$ phosphate buffer ( $\mathrm{pH}$ 7.4) containing $1 \mathrm{~mm}$-DTT and approximately double the original brain weight. This solution was dialyzed for about $20 \mathrm{~h}$ against two changes of 21 each of
$1 \mathrm{~mm}-\mathrm{Na}$ phosphate buffer, $\mathrm{pH}$ 7.4, containing $0.1 \mathrm{~mm}-\mathrm{DTT}$ at $4 \mathrm{C}$. Five to ten millilitres of the dialyzed solution were introduced from the bottom onto a Pharmacia K 26/70 column previously packed with DEAE-cellulose and equilibrated with $10 \mathrm{~mm}-\mathrm{Na}$ phosphate buffer, $\mathrm{pH}$ 7.4, containing $1 \mathrm{~mm}$-DTT. After $125 \mathrm{ml}$ of the equilibrating buffer, elution was begun by means of a convex gradient formed by mixing $125 \mathrm{ml}$ of the equilibrating buffer with $175 \mathrm{ml}$ of the same buffer containing $2 \mathrm{M}-\mathrm{NaCl}$. The flow rate was about $1 \mathrm{ml} / \mathrm{min}$. The effluent was continuously monitored at $280 \mathrm{~nm}$, the fractions containing enzyme activity pooled, dialyzed against 21 of $1 \mathrm{~mm}-\mathrm{Na}$ phosphate buffer, pH 7.4, containing $0.1 \mathrm{~mm}$-DTT and desalted. The volume was reduced to about $5 \mathrm{ml}$ which were introduced from the bottom onto a Pharmacia K 16/70 column packed with Sephadex G-100 and equilibrated with $25 \mathrm{~mm}-\mathrm{Na}$ phosphate buffer, $\mathrm{pH} \mathrm{7.4,} \mathrm{contain-}$ ing $0.5 \mathrm{~mm}-\mathrm{DTT}$. Elution was with the same buffer, also containing $0.3 \mathrm{~m}-\mathrm{NaCl}$. The fractions containing enzyme activity were pooled and stored on ice. Freezing of solutions containing HMT was avoided, as all activity was promptly lost.

Enzyme velocity and kinetic constants. The velocity and/or activity of HMT is expressed as d.p.m. 1-[Me- $\left.{ }^{14} \mathrm{C}\right]-$ methylhistamine formed/30 min. With the knowledge that 8850 d.p.m. represents one nmol of $1-\left[\mathrm{Me}^{14} \mathrm{C}\right]$ methylhistamine. the interconversion between d.p.m. and $\mathrm{nmol}$ is readily attained; for simplicity, we chose to express the velocity of HMT in radioactivity units. except when comparing HMT from control and MSO-treated animals. In that case. HMT velocities are expressed in d.p.m. $/ 30 \mathrm{~min} / \mathrm{mg}$ of protein. The apparent $K_{m}$ and $K_{i}$ values are in $\mathrm{mol} / \mathrm{l}(\mathrm{M})$.

\section{RESULTS}

\section{The purification of rat and mouse brain HMT}

The 4-step purification procedure (Tables 1 and 2) yielded 87- and 166-fold purified enzyme from rat and mouse brain. The recoveries were between 12 and $16 \%$ of the original tissue homogenate activity. Figures 1 and 2 show the elution profiles of HMT on DEAE-cellulose and on Sephadex G-100. Mouse HMT occasionally exhibited two activity peaks or a peak and a shoulder on DEAE-cellulose (see Fig. 1 b), but after Sephadex, such heterogeneity (AXELROD \& Vesell, 1970; Suriyachan \& Thithapandha, 1972) was no longer detectable. Gel-filtration on Sephadex G-100 of the purified enzyme against molecular weight calibration standards yielded a molecular weight of $29,000 \pm 1500$ (range from 2 rat and 2 mouse experiments). The purified enzyme remained active for up to 3 weeks at $4^{\circ} \mathrm{C}$.

\section{Survey of effective amines}

Initially a series of amines were tested at several concentrations $\left(4 \times 10^{-7} \mathrm{M}-2.5 \times 10^{-6} \mathrm{M}\right)$ and with both rat and mouse HMT (purified through the Sephadex step). The concentration of histamine was kept at $1 \times 10^{-5} \mathrm{M}$, previously established as the optimal concentration (Schatz \& Sellinger, 1975a) a fact which was confirmed in preliminary experiments using the purified enzyme. Strong inhibition of HMT 
Table 1. Purification of rat brain histamine $N$-methyltransferase

\begin{tabular}{|c|c|c|c|c|c|c|c|}
\hline \multirow[b]{2}{*}{ Fraction } & \multirow[b]{2}{*}{$\begin{array}{c}\text { Volume } \\
\text { (ml) }\end{array}$} & \multicolumn{2}{|c|}{ Protein } & \multicolumn{2}{|c|}{ Enzyme activity } & \multirow[b]{2}{*}{$\begin{array}{l}\text { Purification } \\
\text { (x-fold) }\end{array}$} & \multirow[b]{2}{*}{$\begin{array}{l}\text { Yield } \\
(\%)\end{array}$} \\
\hline & & $(\mathrm{mg} / \mathrm{ml})$ & $\begin{array}{l}\text { Total } \\
\text { (mg) }\end{array}$ & $\begin{array}{l}\text { Specific } \\
\text { activity }\end{array}$ & $\begin{array}{c}\text { Tctal } \\
\text { activity }\end{array}$ & & \\
\hline $\begin{array}{l}\text { Homogenate } \\
80.000 \mathrm{~g}\end{array}$ & 118 & 18.1 & 2,149 & 780 & $1.68 \times 10^{6}$ & & 100 \\
\hline $\begin{array}{l}\text { supernatant } \\
\text { Ammonium sulfate } \\
\left(45-80^{\circ} \% \text { after }\right.\end{array}$ & 95.5 & 5.5 & 530 & 1,860 & $9.85 \times 10^{5}$ & 2.4 & 59.2 \\
\hline $\begin{array}{l}\text { dialysis) } \\
\text { DEAE-cellulose } \\
\text { (after eluate }\end{array}$ & 10.0 & 1.23 & 123 & 4,530 & $5.57 \times 10^{5}$ & 5.8 & 33.3 \\
\hline $\begin{array}{l}\text { concentration) } \\
\text { Sephadex G-100 }\end{array}$ & $\begin{array}{r}4.4 \\
32.3\end{array}$ & $\begin{array}{l}1.23 \\
0.088\end{array}$ & $\begin{array}{l}5.45 \\
2.85\end{array}$ & $\begin{array}{l}45,200 \\
68,200\end{array}$ & $\begin{array}{l}2.47 \times 10^{5} \\
1.94 \times 10^{5}\end{array}$ & $\begin{array}{l}57.6 \\
87.3\end{array}$ & $\begin{array}{l}14.7 \\
11.6\end{array}$ \\
\hline
\end{tabular}

Table 2. Purification of mouse brain histamine $N$-methyltransferase

\begin{tabular}{|c|c|c|c|c|c|c|c|}
\hline \multirow[b]{2}{*}{ Fraction } & \multirow[b]{2}{*}{$\begin{array}{l}\text { Volume } \\
(\mathrm{ml})\end{array}$} & \multicolumn{2}{|c|}{ Protein } & \multicolumn{2}{|c|}{ Enzyme activity } & \multirow[b]{2}{*}{$\begin{array}{c}\text { Purification } \\
\text { ( } x \text {-fold })\end{array}$} & \multirow[b]{2}{*}{$\begin{array}{l}\text { Yield } \\
(\%)\end{array}$} \\
\hline & & $(\mathrm{mg} / \mathrm{ml})$ & $\begin{array}{l}\text { Total } \\
(\mathrm{mg})\end{array}$ & $\begin{array}{l}\text { Specific } \\
\text { activity }\end{array}$ & $\begin{array}{c}\text { Total } \\
\text { activity }\end{array}$ & & \\
\hline Homogenate & 73 & 13.3 & 967 & 1,580 & $1.53 \times 10^{6}$ & - & 100 \\
\hline Ammonium sulfate & 70 & 3.54 & 248 & 2,850 & $7.04 \times 10^{5}$ & 1.8 & 46.0 \\
\hline $\begin{array}{l}\text { dialysis) } \\
\text { DEAE-cellulose } \\
\text { (after eluate }\end{array}$ & 10.3 & 2.23 & 22.3 & 39.300 & $8.75 \times 10^{5}$ & 25.0 & 57.0 \\
\hline concentration) & 5.6 & 0.35 & 1.97 & 173.320 & $3.41 \times 10^{5}$ & 109.2 & 22.2 \\
\hline Sephadex G-100 & 26.3 & 0.035 & 0.93 & 261,800 & $2.47 \times 10^{5}$ & 166.0 & 16.2 \\
\hline
\end{tabular}

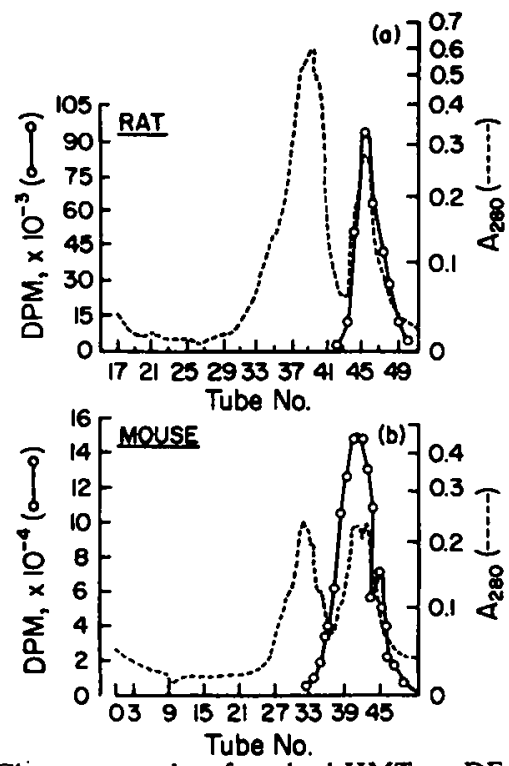

FIG. 1. Chromatography of cerebral HMT on DEAE cellulose. (a) After exhaustive dialysis of the $45-80 \%\left(\mathrm{NH}_{4}\right)_{2} \mathrm{SO}_{4}$ precipitate suspended in $10 \mathrm{~mm}$-Na-phosphate buffer, $\mathrm{pH}$ 7.4, also containing $1 \mathrm{~mm}-\mathrm{DTT}$, the enzyme $(10 \mathrm{ml}, 12.3 \mathrm{mg}$ of protein) was loaded onto a DEAE-cellulose column (see text) and eluted by means of a gradient increasing in $\mathrm{NaCl}$ (see text for details). The left ordinate, $\mathrm{O}-\mathrm{O}$. denotes $1-\left[\mathrm{Me}^{14} \mathrm{C}\right]$ methylhistamine formed $/ 30 \mathrm{~min}$ : ........: absorbance at $280 \mathrm{~nm}$ tracing the elution of protein. (b) As in (a), except that a mouse brain HMT preparation $(10.3 \mathrm{ml}, 23 \mathrm{mg}$ of protein) was chromatographed. Note second peak of HMT activity, $0-0$ (tubes 42-47) and also the left ordinate scale (HMT activity) is 10 times higher than in (a).

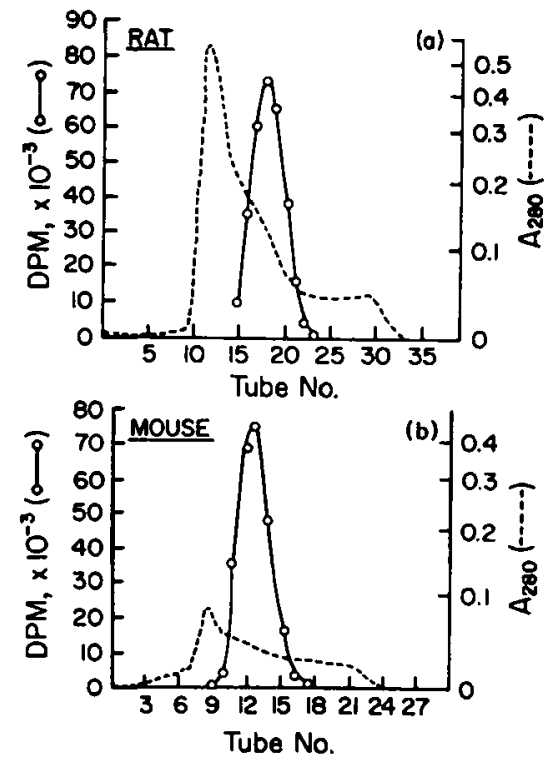

FIG. 2. Gel-filtration of cerebral HMT on Sephadex G-100. (a) The pooled eluate of the DEAE cellulose column (Fig. 1) (4.4 ml, $5.4 \mathrm{mg}$ of protein) was applied to a column of Sephadex G-100 (see text, for details) and the rat brain HMT was eluted as described in the text. The left ordinate denotes $1-\left[\mathrm{Me}^{14} \mathrm{C}\right]$ Methylhistamine formed (d.p.m.)/30 min (O-O) tracing the elution of protein. (b) As in (a) except that $5.6 \mathrm{~m}(1.96 \mathrm{mg})$ of mouse brain protein were applied to the column. 
was achieved by dopamine, tyramine, octopamine, 3-methoxydopamine and 4-methoxyphenethylamine. over the $4 \times 10^{-7} \mathrm{M}-2.5 \times 10^{-6} \mathrm{M}$ range of concentrations. Weak inhibition was seen with 4-methoxydopamine. No inhibition was noted with $2.5 \times 10^{-6} \mathrm{M}$ synephrine, $N$-methyldopamine, 3,4-dimethoxyphenylethylamine, L-3-methoxy-tyrosine, 5-methoxy-DLtryptophan, L-1-methylhistidine, 1-methyl-4-imidazoleacetic acid, imidazoleacetic acid, $\alpha$-methyl-DLtyrosine, L-tryptophan, L-dihydroxyphenylalanine, $\alpha$-methyl-DL-histidine, L-3-methylhistidine, 5-hydroxytryptophan, 5-hydroxyindoleacetic acid, imidazole, norepinephrine and 2-methylimidazole. Among the tryptamines, inhibition was noted with tryptamine, S-hydroxytryptamine (MERRIL et al., 1966), 5-methoxytryptamine, $N, N$-dimethyl-5-hydroxytryptamine, $N, N$-dimethyl-5-methoxytryptamine, while $N$-acetyl-5-methoxytryptamine had no effect. N-Methyl-5hydroxytryptamine and N.N-dimethyltryptamine consistently stimulated at $4 \times 10^{-7} \mathrm{M}$ and inhibited at $2.5 \pm 10^{-6} \mathrm{M}$ in a manner analogous to the $H_{1}$ and $\mathrm{H}_{2}$ histamine receptor blockers, mepyramine and burimamide (TAYLOR, 1973). When some of the above listed amines were retested at $2.5 \times 10^{-7} \mathrm{M}$, alone and in pairs, $N, N$-dimethyltryptamine was again found to stimulate HMT. The results shown in Table 3 also indicate that HMT activity was intermediate when determined in the presence of $N, N$-dimethyltryptamine + tryptamine and maximal and minimal. respectively when determined in the presence of either amine alone. While dopamine exerted little influence on the stimulation of HMT by $N, N$-dimethyltryptamine. tryptamine and 5-methoxytryptamine com-
TABLE 3. THE EFFECT OF A COMBINATION OF INHIBITORY AND STIMULATORY AMINES ON MOUSE BRAIN HISTAMINE $N$-METHYLTRANSFERASE

\begin{tabular}{lc}
\hline \multicolumn{1}{c}{ Amine* } & Activity \\
\hline None & 100 \\
Dopamine & 92 \\
Tryptamine & 35 \\
Dopamine + tryptamine & 69 \\
5-Methoxytryptamine & 108 \\
5-Methoxytryptamine + & 95 \\
dopamine & 72 \\
5-Methoxytryptamine + & \\
tryptamine & 159 \\
$N, N$-Dimethyltryptamine & 142 \\
$N, N$-Dimethyltryptamine + & 63 \\
dopamine & \\
$N, N$-Dimethyltryptamine + & 95 \\
tryptamine & \\
$N, N$-Dimethyltryptamine + & \\
5-methoxytryptamine & \\
\hline
\end{tabular}

* $2.5 \times 10^{-7} \mathrm{M}$; histamine: $1 \times 10^{-5} \mathrm{M}$.

The incubations were for $30 \mathrm{~min}$ in the presence of Sephadex-purified mouse brain HMT. Each amine, whether incubated alone or as a member of a pair, was at the concentration indicated.

pletely abolished it even though the latter amine had virtually no effect on HMT when tested alone.

\section{Effect of modulator and histamine concentrations}

In an effort to extend the above observations HMT was incubated in the presence of a wide range $\left(10^{-5} \mathrm{M}-10^{-8} \mathrm{M}\right)$ of concentrations of 5-methoxytryptamine, $\quad N, N$-dimethyltryptamine, $\quad N, N$-dimethyl-5methoxytryptamine, $N$-methyl-5-hydroxytryptamine

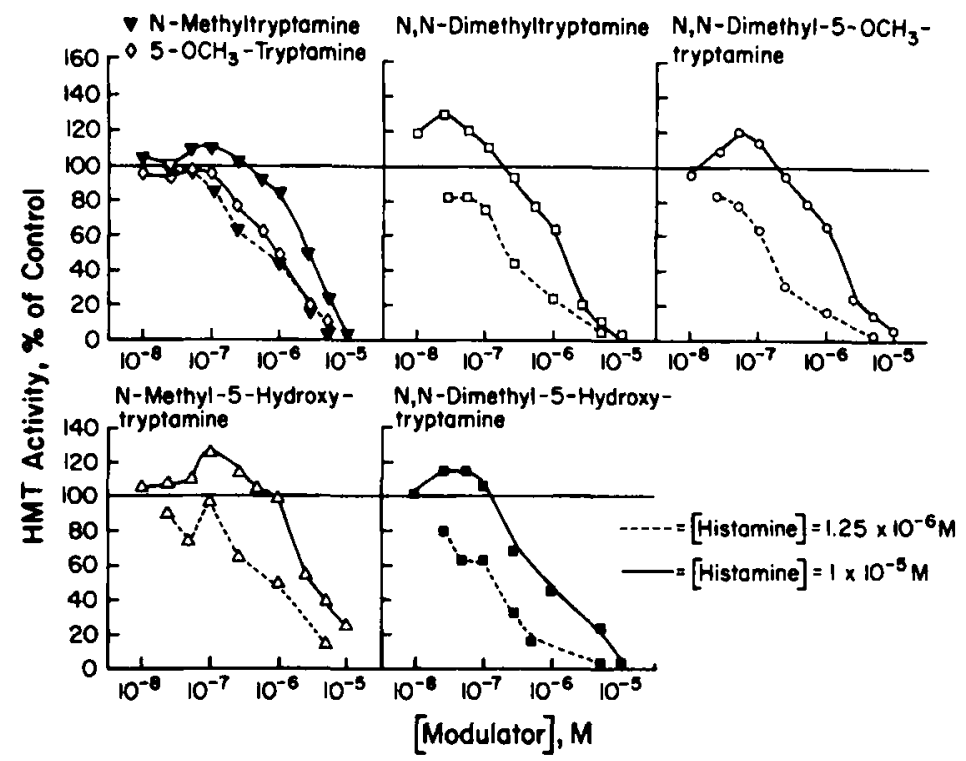

FIG. 3. Effect of modulator concentration on the activity of rat brain HMT. Rat brain HMT, purified through the Sephadex G-100 step (Table 1) was incubated at $1 \times 10^{-5} \mathrm{M}$ and $1.25 \times 10^{-6} \mathrm{M}(\ldots . . .-)$ histamine (except for 5-methoxytryptamine which was not incubated at $1.25 \times 10^{-6} \mathrm{M}$-histamine) and in the presence of the indicated concentrations of 6 methylated indoleamines (modulator) and the amount of $1-\left[\mathrm{Me}^{-14} \mathrm{C}\right]$ methylhistamine formed in $30 \mathrm{~min}$ was determined. The values are plotted as $\%$ of those obtained in the absence of modulator (control HMT $=100 \%$ ). 
and N,N-dimethyl-5-hydroxytryptamine and its activity determined at $1 \times 10^{-5} \mathrm{M}$ and $1.25 \times 10^{-6} \mathrm{M}$ histamine (except for 5-methoxytryptamine). Figure 3 illustrates the typical pattern of stimulation of HMT by a range of amine concentrations $\left(5 \times 10^{-6} \mathrm{M}\right.$ and $1 \times 10^{-8} \mathrm{M}$ ) together with its dependence on the prevailing concentration of histamine. Thus, none of the methylated indoleamines stimulated HMT at the lower histamine concentration. Conversely, HMT was uniformly inhibited at amine concentrations above $5 \times 10^{-6} \mathrm{M}$ and, as indicated in Fig. 3, this inhibition was significantly more severe at the lower of the two histamine concentrations.

The substrate dependence of the stimulation of HMT was further examined by determining its activity over a $10^{-5}-8 \times 10^{-7} \mathrm{M}$ range of histamine concentrations and in the presence of either an inhibitory $\left(1\right.$ or $\left.4 \times 10^{-6} \mathrm{M}\right)$ or a presumed stimulatory $\left(2.5 \times 10^{-7} \mathrm{M}, 7 \times 10^{-8} \mathrm{M}\right.$ or $\left.4 \times 10^{-8} \mathrm{M}\right)$ modulator concentration. The Lineweaver-Burk $(1 / v$ vs $1 / s)$ plots (Fig. 4) show inhibition with the compounds shown effective in Fig. 3 (panels $d$, e and $f$ ) and, unexpectedly, with 5-methoxytryptamine as well (panel c).
Stimulation was limited to a narrow range of histamine concentrations $\left(10^{-5} \mathrm{M}-2.5 \times 10^{-6} \mathrm{M}\right)$.

\section{The nature of the modulator-HMT interaction}

The overall effects of selected methylated indoleamines on HMT activity were further tested by examining them at more than one concentration of histamine. The results of these experiments yielded the Dixon plots ([I] vs. $1 / v)$ shown in Fig. 5 (a-c: mouse; $\mathrm{d}-\mathrm{f}$; rat) and permitted the calculation of selected $K_{i}$ values (Table 4). The deviations from linearity noted in the presence of $N, N$-dimethyltryptamine, 5-methoxytryptamine and $N, N$-dimethyl-5-methoxytryptamine consisted of concave-upwards curvatures in the [I] vs $1 / v$ lines at close to or saturating concentrations of histamine, confirming their HMT-stimulatory action under these conditions (panels $b$, e and f). A comparison of the $K_{i}$ values (Table 4) with the apparent $K_{m}$ value for histamine revealed a non-competitive inhibition by dopamine (Fig. 5 , panels a and d) vs a competitive inhibition by the methylated indoleamines, particularly those containing two or three methyl groups per molecule. To analyze their HMT-
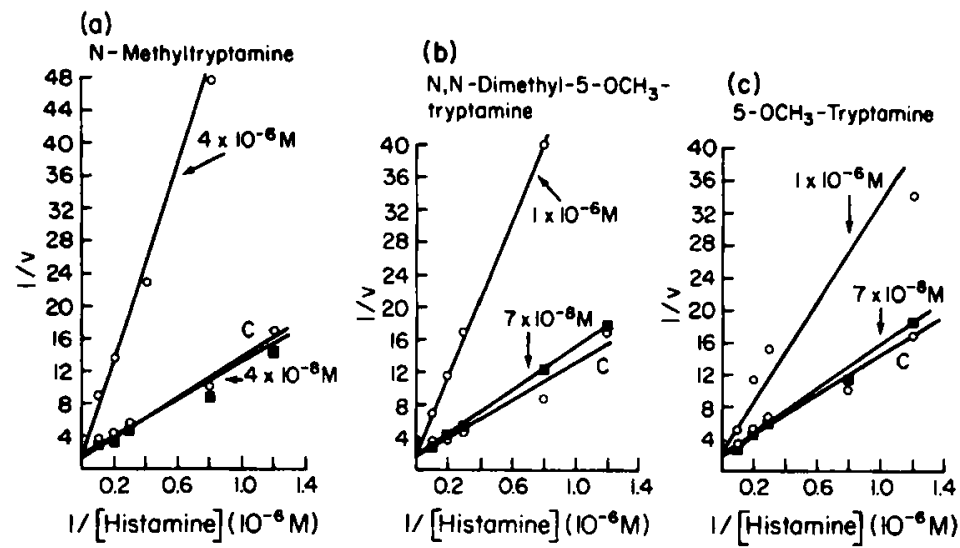

(f) N,N-Dimethyltryptomine

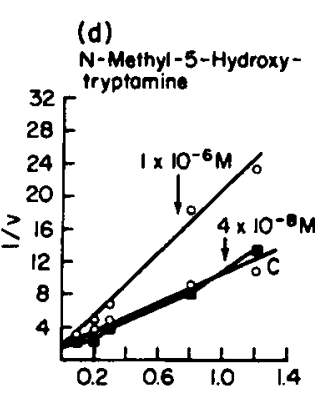

$1 /[$ Histomine $]\left(10^{-6} \mathrm{M}\right)$

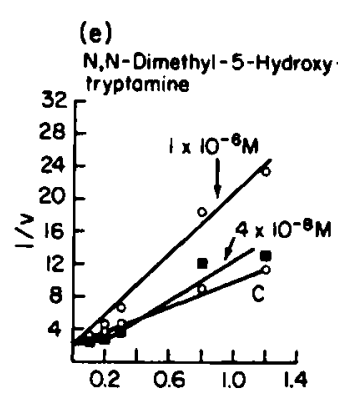

$\mathrm{I} /[$ Histamine $]\left(10^{-6} \mathrm{M}\right)$

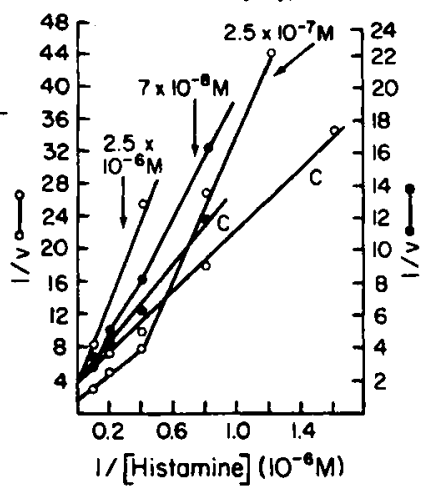

FIG. 4. The modulation of HMT by methylated indoleamines: Lineweaver-Burk plots. All panels: rat brain HMT, except panel f, O-O: mouse brain HMT. $\square$ indicates presence of 4 or $7 \times 10^{-8}$ indoleamine. Note stimulation of HMT in all panels, $v=$ total $1-\left[\mathrm{Me}^{\left.-{ }^{14} \mathrm{C}\right] \text { methylhistamine }}\right.$ (d.p.m.) $/ 30 \mathrm{~min} \times 10^{-6}$, except for panel $\mathrm{f}\left(\mathrm{O}^{-}-\mathrm{O}\right)$ where $v=$ total $1-\left[\mathrm{Me}^{\left.-{ }^{14} \mathrm{C}\right] \text { methylhistamine }}\right.$ (d.p.m.) $/ 30 \mathrm{~min} \times 10^{-7} \mathrm{M}$. Concentrations by the arrows are those of the methylated indoleamine. $\mathrm{C}$ : control. Note that in this experiment $7 \times 10^{-8} \mathrm{M}-N, N$-dimethyltryptamine (panel f) stimulated rat brain HMT $(-)$ only at $1 \times 10^{-5} \mathrm{M}$-histamine, while $2.5 \times 10^{-7} \mathrm{M}-N, N$-dimethyltryptamine stimulated mouse HMT $\left(\mathrm{O}_{-}-\mathrm{O}\right)$ at 3 histamine concentrations. 
(a)

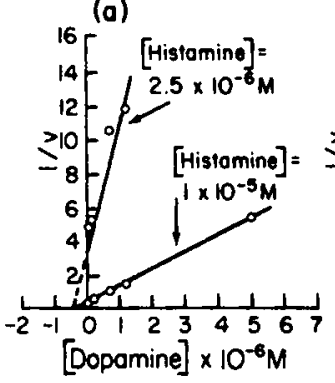

(b)

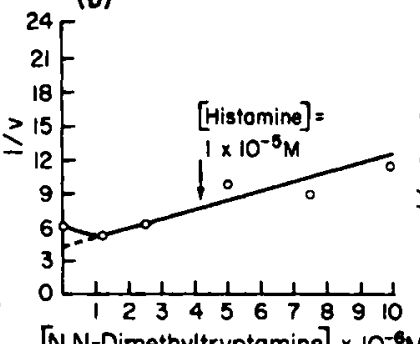

(c)

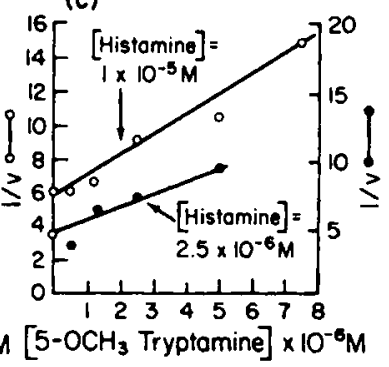

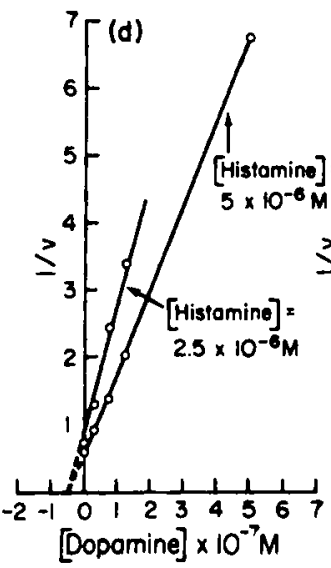
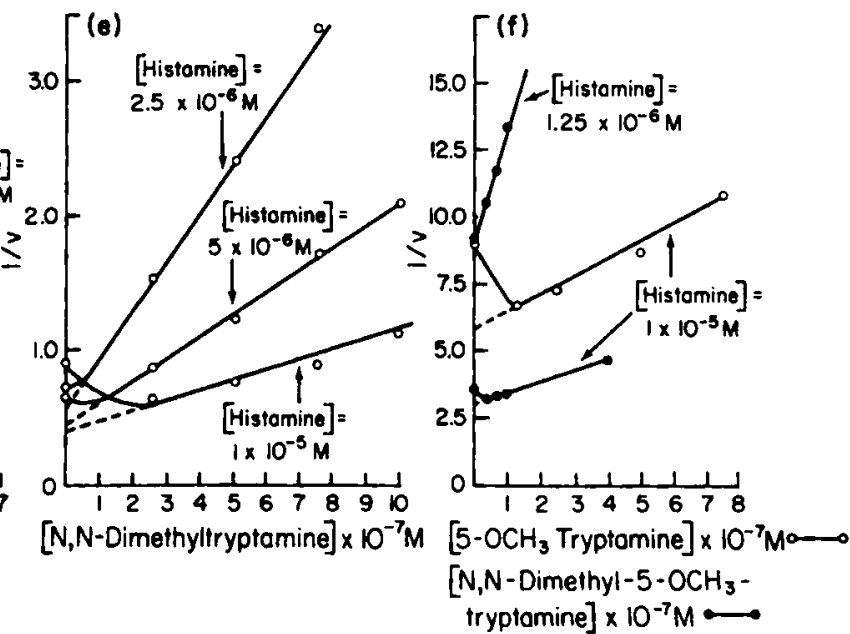

FIG. 5. The modulation of HMT by methylated indoleamines: Dixon plots. Panels a-c: mouse brain HMT; panels d-f: rat brain HMT. In panels a, c (right ordinate), d. e and f. $v=$ total $1-\left[\mathrm{Me}^{-14} \mathrm{C}\right]$

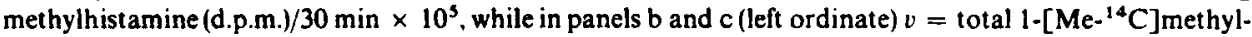
histamine (d.p.m.)/30 $\mathrm{min} \times 10^{6}$. Dotted lines are drawn as if no activation occurred (panels b, e and f) or, in the case of dopamine (panels a and d) they converge on the negative abscissa, indicative of non-competitive inhibition. Note that mouse $(a-c)$ and rat $(\mathrm{d}-\mathrm{n})$ HMT were tested at different modulator concentrations.

stimulatory effectiveness, the methylated indoleamines $\left(10^{-7}-10^{-8} \mathrm{M}\right)$ were incubated with HMT over a 10-fold range of histamine concentrations which included both half and 5-times optimal values. Figure 6 illustrates maximal HMT stimulation at $1 \times 10^{-5} \mathrm{M}$-histamine, with residual stimulation at higher concentrations particularly by the di- and trimethylated compounds. The Lineweaver-Burk representation (Fig. 6b) indicates that. with the exception of $N$-methyltryptamine, the methylated indoleamines stimulated HMT 'non-competitively.'

The action of methylated indoleamines on adrenal phenylethanolamine- $\mathrm{N}$-methyltransferase

Several methylated indoleamines were also tested with rabbit adrenal PNMT. In these experiments the concentration of phenylethanolamine was varied over

TABLE 4. $K_{i}$ VALUES FOR INHIBITION OF RAT AND/OR MOUSE BRAIN hiSTAMINE $N$-METHYLTRANSfERASE by DOPAMINE AND 3 METHYLATED INDOLEAMINES

\begin{tabular}{lccc}
\hline Modulator & \multicolumn{1}{c}{$K_{i}$} & Species & Type of inhibition \\
\hline None & $5.0 \times 10^{-6} \mathrm{M}^{*}$ & rat, mouse & - \\
Dopamine & $4.5 \times 10^{-8} \mathrm{M}$ & rat & non-competitive \\
Dopamine & $4.0 \times 10^{-7} \mathrm{M}$ & mouse & non-competitive \\
$N, N$-Dimethyltryptamine & $7.0 \times 10^{-8} \mathrm{M}+$ & rat & competitive \\
$N, N$-Dimethyl-5-methoxytryptamine & $1.6 \times 10^{-7} \mathrm{M}+$ & rat & competitive \\
5-Methoxytryptamine & $1.2 \times 10^{-6} \mathrm{M}$ & mouse & competitive \\
\hline
\end{tabular}

- $K_{m}$ (Mean of 13 determinations).

† Determined by extrapolation of dashed lines, panels (e) and (f), Fig. 5 and on the assumption of no HMT stimulation.

The $K_{i}$ values were obtained graphically from the Dixon plots, shown in Fig. 5. Sephadex-purified HMT was used for all determinations. 
(b)

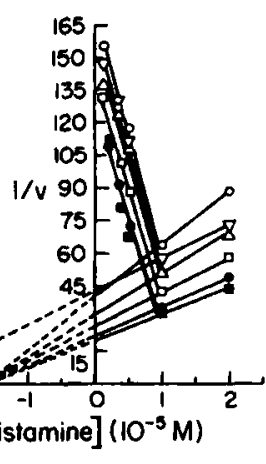

(a)

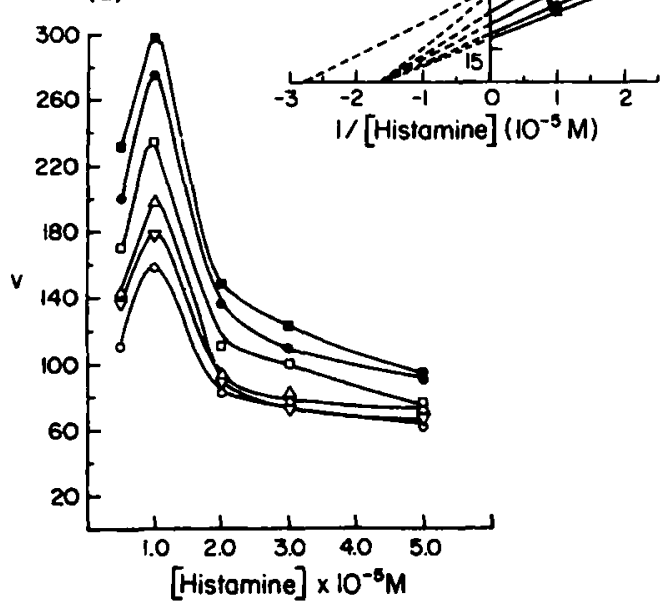

FIG. 6. The modulation of rat brain HMT by methylated indoleamines in the presence of inhibitory concentrations of histamine. (a) Michaelis-Menten plot. $v=$ total $1-\left[\mathrm{Me}-{ }^{14} \mathrm{C}\right]$ methylhistamine (d.p.m.) $/ 30 \mathrm{~min} \times 10^{3}$. O: control; $\nabla: 1 \times 10^{-7} \mathrm{M}-N$-methyltryptamine; $\Delta: 1 \times 10^{-7} \mathrm{M}$ $N$-methyl-5-hydroxytryptamine; $\square: \quad 7 \times 10^{-8} \mathrm{M}-N, N$ dimethyltryptamine; $7 \times 10^{-8} \mathrm{M}-N, N$-dimethyl-5-methoxytryptamine and $7 \times 10^{-8} \mathrm{M}-N, N$-dimethyl-5-hydroxytryptamine. (b) Lineweaver-Burk plot of (a). $v=$ total $1-\left[\mathrm{Me}^{14} \mathrm{C}\right]$ methylhistamine (d.p.m.) $/ 30 \mathrm{~min} \times 10^{-3} \mathrm{M}$. a 20-fold range which included the apparent saturating concentration (ca. $5 \times 10^{-5} \mathrm{M}$ ) and the reported $K_{m}$ concentration $\left(0.4 \times 10^{-5} \mathrm{M}\right.$; LEW et al., 1976). Table 5 illustrates the two main features of the methyl-indoleamine-PNMT interaction: (a) a marked inhibition by $N$-methyltryptamine which appeared to decrease as the concentration of the substrate was raised; and (b) a tendency toward stimulation of the enzyme by $N$-methyl-5-hydroxytryptamine and $N, N$ dimethyl-5-hydroxytryptamine; 5-methoxytryptamine and $N, N$-dimethyltryptamine were without effect (data not shown).

Histamine N-methyltransferase from MSO-treated animals (MSO-HMT)

Several experiments were carried out in which mice or rats were pretreated for $3 \mathrm{~h}$ with a convulsant dose of MSO $(0.97 \mathrm{mmol} / \mathrm{kg})$ and HMT was then purified through the Sephadex step to be compared to the control enzyme purified in parallel. Control and MSO-HMT were incubated over a 10-fold range of histamine concentrations in the presence of $7 \times 10^{-8} \mathrm{M}-N, N$-dimethyltryptamine (a stimulatory concentration, see Figs. 3 and 5) as well as over a 100-fold range of $N, N$-dimethyltryptamine concentrations at $1 \times 10^{-5} \mathrm{M}$ and $1.25 \times 10^{-6} \mathrm{M}$-histamine. These studies revealed that MSO-HMT was also stimulated by $N, N$-dimethyltryptamine at close to saturating concentrations of histamine and that the control and the MSO-HMT exhibited closely similar $K_{i}$ values for $N, N$-dimethyltryptamine (ca. $\left.7 \times 10^{-8} \mathrm{M}\right)$ when determined at $1 \times 10^{-5} \mathrm{M}$-histamine.

TAble 5. The action of methylated indoleamines on adRenal PHenYlethanolamine $N$-Methyltransferasf: DePENDENCE ON SUBSTRATE CONCENTRATION

\begin{tabular}{|c|c|c|c|c|c|c|}
\hline \multirow{4}{*}{$\begin{array}{l}\text { Methylated } \\
\text { indoleamine } \\
\text { Expt. 1 } \\
\text { None, units* }\end{array}$} & \multicolumn{6}{|c|}{ [Phenylethanolamine] $\times 10^{-5} \mathrm{M}$} \\
\hline & \multirow[t]{2}{*}{0.42} & \multicolumn{2}{|c|}{$0.65 \quad 1.6$} & 2.5 & 5.0 & \multirow[t]{2}{*}{10} \\
\hline & & & & & & \\
\hline & 868 & 1086 & 1523 & 1501 & 1484 & 1387 \\
\hline $\begin{array}{l}\text { None, \% } \\
N \text {-Methyltryptamine }\end{array}$ & 100 & 100 & 100 & 100 & 100 & 100 \\
\hline $4 \times 10^{-7} M$ & 43 & 50.5 & 47 & 60 & 75.5 & 84.5 \\
\hline $1 \times 10^{-6} \mathrm{M}$ & 25 & 32.5 & 38.5 & 60 & 59 & 70.5 \\
\hline \multicolumn{7}{|l|}{ Expt. 2} \\
\hline None, Units* & 1394 & 1859 & 2057 & 1932 & 2441 & 2000 \\
\hline $\begin{array}{l}\text { None, \% } \\
N \text {-Methyl-5-hydroxytryptamine }\end{array}$ & 100 & 100 & 100 & 100 & 100 & 100 \\
\hline $4 \times 10^{-8} \mathrm{M}$ & 88 & 82 & 97 & 114 & 87 & 100 \\
\hline $1 \times 10^{-7} M$ & 89 & 83 & 111 & 122 & 99 & 100 \\
\hline$N, N$-Dimethyl-5-hydroxytryptamine & & & & & & \\
\hline $4 \times 10^{-8} \mathrm{M}$ & 93 & 96 & 117 & 122 & 92 & 103 \\
\hline $1 \times 10^{-7} \mathrm{M}$ & 68 & 66.5 & 102 & 102 & 98 & 100 \\
\hline
\end{tabular}

* d.p.m. of $\left[{ }^{14} \mathrm{C}\right]$ methylated product/h.

The contents of a vial of rabbit adrenal PNMT $(14 \mathrm{mg})$ as supplied. were dissolved in one $\mathrm{ml}$ of distilled water and $0.05 \mathrm{ml}$ used per assay. Incubations were at $37^{\circ} \mathrm{C}$ for $30 \mathrm{~min}$. The remainder of the enzymic determination was as described by DEGUCHI \& BARCHAS (1971). 


\section{DISCUSSION}

The present study is the first to report an extensive purification of cerebral HMT. On the average, the procedure outlined in Tables 1 and 2 yielded rat and mouse brain HMT 2.5 and 4.6 times purer than the previously available 36 -fold purified guinea-pig brain HMT (Brown et al. 1959). Efforts to purify HMT from non-neural tissues have yielded a 260 -fold purified pig-liver preparation (GuSTAFsSON \& Forschell, 1963) and a 120-fold purified. but highly unstable, HMT preparation from the mucosa of the pig antrum (LORENZ et al., 1972). It is of interest to note that TAYLOR \& SNYDER (1972) used merely 6-fold purified mouse brain HMT to carry out a comprehensive study of its inhibition and potentiation by antihistamines.

The molecular weight of 29,000 for the rat and mouse brain HMT compares with the recently reported molecular weights of 25,000 and 26,000 respectively, for cerebral catechol $O$-methyltransferase (COMT, EC 2.1.1.6) (WhITE \& Wu, 1975) and PNMT (DiAz Borges \& Urbina, 1976). However, in view of: (a) the differential regional and cellular localizations of HMT, PNMT and COMT in brains of different species (SaAvedra et al., 1974; Garbarg et al., 1975; MezeI, 1975; SAAVEdRA et al, 1976a; VoGEL et al. 1976; LEw et al., 1977); (b) their different developmental patterns (MARTRES et al., 1975; MEZEl. 1975; Kouvelas et al., 1976); (c) their different patterns of molecular heterogeneity (AXELROD \& VESELL, 1970; Suriyachan \& ThIThapandha, 1972; White \& WU, 1975); and (d) their different sensitivities toward different modulating processes (ORR \& QUAY, 1975; Schatz \& Sellinger, 1975a; SaAvedra et al., 1976b), any inference regarding molecular similarities among the three methyltransferases and, hence, by extension, of common mechanisms regulating their activities in vivo is at this time premature.

Although cerebral HMT is affected in vitro by a wide variety of pharmacologic agents (TAYLOR \& SNYDER, 1972; BARTH et al., 1973; SCHAYER \& REILly, 1975; Duch et al., 1976) some of which act in an apparent stimulatory manner (TAYLOR \& SNYDER, 1972; BARTH et al.. 1973; TAYLOR, 1973), its modulation by methylated indoleamines has not been described. HARTLEY \& SMITH (1973) recently reported a significant stimulation of the bovine pineal hydroxyindole $O$-methyltransferase by $N, N$-dimethyltryptamine and $N, N$-dimethyl-5-methoxytryptamine (tested at $1.2 \times 10^{-4} \mathrm{M}$ ). The modulation of cerebral HMT by the methylated indoleamines consisted of inhibition and stimulation in a manner strictly dependent on the prevailing concentration of histamine. Figures 3 and 4 summarize the effects of 6 methylated indoleamines. As may be seen (Fig. 4), HMT inhibition by $1-4 \times 10^{-6} \mathrm{M}$ modulator was competitive with respect to histamine. Stimulation of HMT was noted at or close to $1 \times 10^{-5} \mathrm{M}$-histamine and was achieved at $47 \times 10^{-8} \mathrm{M}$ (rat) or $2.5 \times 10^{-7} \mathrm{M}$ (mouse) modulator.
Our findings thus reveal that methylated indoleamines "can go from inhibition to stimulation (or the reverse) by varying the substrate" (REINER, 1959). A similar situation was recently described by LOMBARDIN et al. (1973) with ATP: L-methionine $S$-adenosyltransferase (EC 2.5.1.6) of rat liver, an enzyme we recently compared in rat brain cerebral cortex and cerebellum (Diez Altares \& Sellinger, 1976). These workers noted activation of the enzyme by 'low' $\left(0.7-2 \times 10^{-3} \mathrm{M}\right)$ and inhibition by 'high' (3.5-16.5 $\left.\times 10^{-3} \mathrm{M}\right)$ concentrations of several modulators, both effects being strongly dependent on the concentration of one of the substrates, L-methionine. However, unlike in the present study, high concentrations of methionine led to inhibition rather than stimulation of the enzyme. Thus the present and seemingly unique situation in which low $\left(10^{-7}-10^{-8} \mathrm{M}\right)$ modulator concentrations stimulate HMT maximally at, or close to, saturating substrate concentrations (Fig. 6) appears to rule out mechanisms based on "cooperative effects between successively bound molecules' (Lombardini et al., 1973). Presently, we prefer a mechanism of stimulation wherein the modulator affects a regulatory site of HMT and in so doing improves the interaction and/or the fit of the saturating histamine with the catalytic site of the enzyme. It is of interest that some of the substances found effective in the present study have previously been implicated as neuro-or schizotoxins (Rosengarten \& Friedhoff, 1976; Gillin et al., $1976 a, b)$. The epileptogenic action of MSO could therefore derive from the drug's ability to bring about a certain degree of 'hypermethylation'. Evidence in support of this possibility continues to accrue (Schatz et al., 1976, 1977; Schatz \& Sellinger. 1977; Salas et al., 1977).

\section{REFERENCES}

Axelrod J. \& Vesell E. S. (1970) Molec. Pharmac. 6, 78-84.

Barth H. Lorenz W. \& Niemeyer I. (1973) HoppeSeyler's Z. Physiol. Chem. 354, 1021-1026.

Brown D. D., TOMCHICK R. \& AxelRoD J. (1959) J. biol. Chem. 234, 2948-2950.

Deguchi T. \& Barchas J. (1971) J. biol. Chem. 246, 3175-3181.

Diaz Borges J. M. \& Urbina CH. M. (1976) Abstr. 31st Meet. Soc. Biol. Psych. p. 117.

Diez Altares M. C. \& Sellinger O. Z. (1976) Enzyme 21, 53-65.

Duch D. S., Bowers S. W. Brenckman W. D.. JR. \& Nichol. C. A. (1976) Pharmacologist 18, 205.

Garbarg M., Baudry M., Benda P. \& Schwartz J.-C. (1975) Brain Res. 83, 538-541.

Gillin J. C., Kaplan J., Stillman R. \& Wyatt R. J. (1976a) Am. J. Psychiat. 133, 203-208.

Gillin J. C., Tinklenberg J., Stoff D. M., Stillman R.. Shortlidge J. \& Wyatt R. J. (1976b) Biol. Psych. 11, 355-358.

Gustafsson A. \& Forschell G. P. (1963) Acia Chem. scand. 17, 541-548. 
Hartley R. \& Smith J. A. (1973) J. Pharm. Pharmac. 25, 751-752.

Kouvelas E. D., Savakis Ch. E., Tzebelikos T., Bonatsos G. \& Mitrossilis S. (1976) Experientia 32, 1136-1138.

Lew J. Y., Matsumoto Y., Pearson J., Goldstein M.. HokfELT T. \& FuXE K. (1977) Brain Res. 119, 199-210.

LeW J. Y. MiYamoto T. \& Goldstein M. (1976) Biochem. Pharmac. 25, 1433-1434.

lombardini J. B., Chou T.-C. \& Talalay P. (1973) Biochem. J., Land. 135, 43-57.

Lorenz W., ReimanN H.-J., Barth J., Kusche J., Meyer R., Doenicke A. \& Hutzel M. (1972) Hoppe Seyler's Z. Physiol. Chem. 353, 911-920.

Lowry O. H., Rosebrough N. J.. FARR A. L. \& RANDALL R. J. (1951) J. biol. Chem. 193, 265-275.

Martres M. P., Baudry M. \& Schwartz J.-C. (1975) Brain Res. 83, 261-275.

MerRil C. R., Snyder S. H. \& Bradley D. F. (1966) Biochim. biophys. Acta 118, 316-324.

MEZE1 C. (1975) Brain Res. 84, 453-460.

ORR E. \& QUAY W. B. (1975) Endocrinology 96, 941-945.

Reiner J. M. (1959) in Behavior of Enzyme Systems. p. 176. Burgess Minneapolis, MN.

Rosengarten H. \& FrIedhoff A. J. (1976) Schizophrenia Bull. 2, 90-105.

SaAvedra J. M., Brownstein M. J. \& Palkovits M. (1976) Brain Res. 118, 152-156.

SAAVEDRA J. M. GROBECKer H. \& AXELROD J. (1975) Science 191, 483-484.
Sanvedra J. M., Palkovits M., Brownstein M. J. \& AXELROD J. (1974) Nature 248, 695-696.

Salas C. E., Ohlsson W. G. \& Sellinger O. Z. (1977) Biochem. Biophys. Res. Commun. 76, 1107-1115.

Schatz R. A., Harris R. \& Sellinger O. Z. (1976) Neurochem. Res. 1, 53-63.

Schatz R. A. \& Sellinger O. Z. (1975a) J. Neurochem. 25, 73-78.

Schatz R. A. \& Sellinger O. Z. (1975b) J. Neurochem. 24, 63-66.

Schatz R. A. \& Sellinger O. Z. (1977) Pharmacologist $19,187$.

Schatz R. A.. Vunnam C. R. \& Sellinger O. Z. (1977) Neurochem. Res. 2, 27-38.

SChayer R. W. \& Reilly M. A. (1975) Agents \& Actions 5. 231-235.

Sellinger O. Z., Schatz R. A., Ashcraft E. K. \& OhlsSoN W. G. (1976) Trans. Am. Soc. Neurochem. 7. 237. SNYDER S. H. \& AXELROD J. (1965) Biochim. biophys. Acta $111,416-421$.

Suriyachan D. \& Thithapandha A. (1972) Biochem. biophys. Res. Commun. 48, 1199-1207.

TAYLOR K. M. (1973) Biochem. Pharmac. 22, 2775-2776. TAYlor K. M. \& SNYder S. H. (1972) Molec. Pharmac. 8, 300-310.

Vogel W. H., Lewis L. E. \& Boehme D. M. (1976) Brain Res. 115, 357-359.

WhITE H. L. \& WU J. C. (1975) Biochem. J., Lond. 145, 135-143. 